\title{
Membrane Penetration by Synaptotagmin Is Required for Coupling Calcium Binding to Vesicle Fusion In Vivo
}

\author{
Brie E. Paddock, ${ }^{1}$ Zhao Wang, ${ }^{2 \star}$ Laurie M. Biela, ${ }^{1 \star}$ Kaiyun Chen, ${ }^{3 \star}$ Michael D. Getzy, ${ }^{1}$ Amelia Striegel, ${ }^{1}$ \\ Janet E. Richmond, ${ }^{3}$ Edwin R. Chapman, ${ }^{2}$ David E. Featherstone, ${ }^{3}$ and Noreen E. Reist ${ }^{1}$ \\ ${ }^{1}$ Program in Molecular, Cellular, and Integrative Neuroscience, Department of Biomedical Sciences, Colorado State University, Fort Collins, Colorado \\ 80523, ${ }^{2}$ Department of Physiology and Howard Hughes Medical Institute, University of Wisconsin, Madison, Wisconsin 53706, and ${ }^{3}$ Department of \\ Biological Sciences, University of Illinois at Chicago, Chicago, Illinois 60607
}

The vesicle protein synaptotagmin $\mathrm{I}$ is the $\mathrm{Ca}^{2+}$ sensor that triggers fast, synchronous release of neurotransmitter. Specifically, $\mathrm{Ca}^{2+}$ binding by the $\mathrm{C}_{2} \mathrm{~B}$ domain of synaptotagmin is required at intact synapses, yet the mechanism whereby $\mathrm{Ca}^{2+}$ binding results in vesicle fusion remains controversial. $\mathrm{Ca}^{2+}$-dependent interactions between synaptotagmin and SNARE (soluble $\mathrm{N}$-ethylmaleimide-sensitive fusion protein attachment receptor) complexes and/or anionic membranes are possible effector interactions. However, no effectorinteraction mutations to date impact synaptic transmission as severely as mutation of the $\mathrm{C}_{2} \mathrm{~B} \mathrm{Ca}^{2+}$-binding motif, suggesting that these interactions are facilitatory rather than essential. Here we use Drosophila to show the functional role of a highly conserved, hydrophobic residue located at the tip of each of the two $\mathrm{Ca}^{2+}$-binding pockets of synaptotagmin. Mutation of this residue in the $\mathrm{C}_{2} \mathrm{~A}$ domain (F286) resulted in a $\sim 50 \%$ decrease in evoked transmitter release at an intact synapse, again indicative of a facilitatory role. Mutation of this hydrophobic residue in the $\mathrm{C}_{2} \mathrm{~B}$ domain (I420), on the other hand, blocked all locomotion, was embryonic lethal even in syt I heterozygotes, and resulted in less evoked transmitter release than that in syt ${ }^{\text {null }}$ mutants, which is more severe than the phenotype of $\mathrm{C}_{2} \mathrm{~B}$ $\mathrm{Ca}^{2+}$-binding mutants. Thus, mutation of a single, $\mathrm{C}_{2} \mathrm{~B}$ hydrophobic residue required for $\mathrm{Ca}^{2+}$-dependent penetration of anionic membranes results in the most severe disruption of synaptotagmin function in vivo to date. Our results provide direct support for the hypothesis that plasma membrane penetration, specifically by the $\mathrm{C}_{2} \mathrm{~B}$ domain of synaptotagmin, is the critical effector interaction for coupling $\mathrm{Ca}^{2+}$ binding with vesicle fusion.

\section{Introduction}

During synaptic transmission, $\mathrm{Ca}^{2+}$ influx into the presynaptic terminal triggers fast, synchronous neurotransmitter release. This process requires mechanisms both for sensing $\mathrm{Ca}^{2+}$ and subsequently fusing transmitter-filled synaptic vesicles with the presynaptic membrane. The SNARE (soluble $\mathrm{N}$-ethylmaleimidesensitive fusion protein attachment receptor) proteins are required for vesicle fusion events in both constitutive and $\mathrm{Ca}^{2+}$ regulated vesicle transport pathways (Jahn and Scheller, 2006). At the nerve terminal, however, additional levels of regulation are required to prevent the fusion of synaptic vesicles with the presynaptic membrane before $\mathrm{Ca}^{2+}$ entry and then expedite the synchronous fusion of multiple vesicles when $\mathrm{Ca}^{2+}$ levels rise. The synaptic vesicle protein synaptotagmin (syt) is the major

\footnotetext{
Received July 2, 2009; revised Nov. 29, 2010; accepted Dec. 6, 2010.

This work was supported by National Institutes of Health Grant NS045865 (N.E.R.) and MH073156-04S1 (J.E.R.) National Science Foundation Grants IOS-1025966 and IOS-9982862 (N.E.R.), March of Dimes (N.E.R.), and Microscope Imaging Network, Colorado State University (N.E.R.). We thank M. Tamkun and S. Kinnamon for critical reading of this manuscript.

*Z.W., L.M.B., and K.C. contributed equally to this work.

Correspondence should be addressed to Dr. Noreen E. Reist, Department of Biomedical Sciences, Colorado State University, Fort Collins, C0 80523. E-mail: Noreen.Reist@Colostate.edu.

B. E. Paddock's present address: Department of Biological Sciences, University of the Sciences in Philadelphia, 600 South 43rd Street, Philadelphia, PA 19104.

DOI:10.1523/JNEUROSCI.3153-09.2011

Copyright $\odot 2011$ the authors $\quad 0270-6474 / 11 / 312248-10 \$ 15.00 / 0$
}

$\mathrm{Ca}^{2+}$ sensor that both participates in reducing spontaneous fusion events in the absence of $\mathrm{Ca}^{2+}$ and triggers the synchronous fusion of synaptic vesicles with the presynaptic membrane during $\mathrm{Ca}^{2+}$ influx (DiAntonio and Schwarz, 1994; Geppert et al., 1994; Littleton et al., 1994; Chicka et al., 2008). Thus, synaptotagmin is a key regulator of SNARE-mediated fusion during synaptic transmission.

Specifically, $\mathrm{Ca}^{2+}$ binding by the $\mathrm{C}_{2} \mathrm{~B}$ domain of synaptotag$\mathrm{min}$ is required to trigger fast synchronous vesicle fusion (Mackler et al., 2002; Nishiki and Augustine, 2004). Mutations within the $\mathrm{C}_{2} \mathrm{~B} \mathrm{Ca}^{2+}$-binding motif (see Fig. 1, $\mathrm{C}_{2} \mathrm{~B}, \mathrm{D}_{1}-\mathrm{D}_{4}$ ) result in more severe deficits than complete removal of synaptotagmin I (Geppert et al., 1994; Loewen et al., 2001; Mackler et al., 2002; Nishiki and Augustine, 2004). Such mutations not only block $\mathrm{Ca}^{2+}$-evoked, synchronous release at an intact synapse and result in lethality but also dominantly inhibit the ability of wild-type (WT) synaptotagmin to trigger fusion when these proteins are coexpressed (Mackler et al., 2002). However, the mechanism that couples $\mathrm{Ca}^{2+}$ binding by synaptotagmin with vesicle fusion remains controversial. Any downstream, effector interactions required for coupling $\mathrm{Ca}^{2+}$-bound synaptotagmin to vesicle fusion should cause as severe an effect as mutation of the $\mathrm{C}_{2} \mathrm{~B} \mathrm{Ca}{ }^{2+}$ binding site itself. Biochemical experiments and work on cultured cells suggest that $\mathrm{Ca}^{2+}$-dependent interactions with the SNARE complex and $\mathrm{Ca}^{2+}$-dependent interactions with the presynaptic membrane are likely candidates for effector interactions 
A

$\mathrm{C}_{2} \mathrm{~A}$

RsytI 214 VPYSELGGKTLVMAVYDFDRFSKHDIIGEFKVPMNTVDFGH 254

Dsytl 266 LP Y A D A M N K T V FA I FD F D R F S K H DQ I G EVK V P L CTID L A Q 306

\section{$\mathrm{C}_{2} \mathrm{~B}$}

$\beta-6$

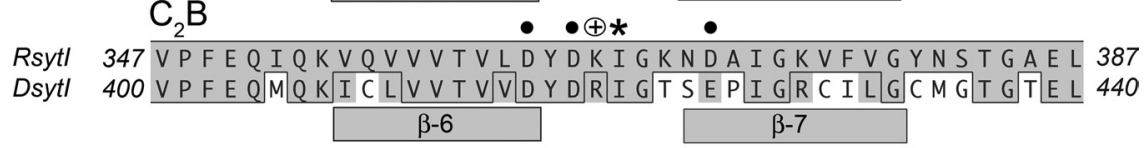

B
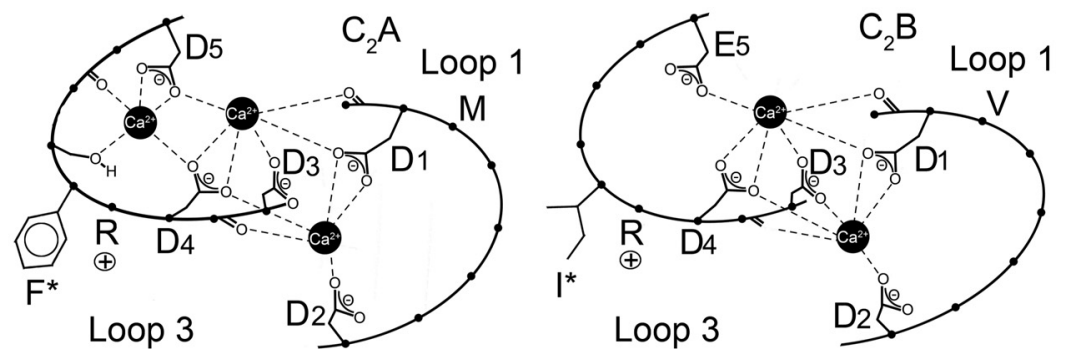

Figure 1. Both the $C_{2} A$ and $C_{2} B$ domains of synaptotagmin have conserved hydrophobic residues at the tip of the $\mathrm{Ca}^{2+}$-binding pocket. $\boldsymbol{A}$, Alignment of synaptotagmin I from rat and Drosophila. Bars indicate $\beta$-sheets, asterisks indicate the conserved hydrophobic residues mutated in this study, dots indicate $\mathrm{C}^{2+}$-binding residues, and open circles with a plus indicate conserved basic residues. Within the alignment, conserved residues are shown in gray and identical residues are boxed. $\boldsymbol{B}$, Schematic representation of loops 1 and 3 in Drosophila that form the $\mathrm{Ca}^{2+}$-binding pockets of each $\mathrm{C}_{2}$ domain. $\mathrm{D}_{1}-\mathrm{D}_{5}$ and $\mathrm{E}_{5}$ indicate $\mathrm{Ca}^{2+}$-binding residues. $F^{*}, M, I^{*}$, and $V$ indicate hydrophobic residues at the tip of the $\mathrm{Ca}^{2+}$-binding pockets.

(Chapman et al., 1995; Gerona et al., 2000; Fernández-Chacón et al., 2001; Bai et al., 2002; Rhee et al., 2005; Herrick et al., 2006; Lynch et al., 2007). However, all mutations that disrupt these interactions that have been examined at synapses result in only a partial disruption in fusion (Fernández-Chacón et al., 2001; Li et al., 2006; Paddock et al., 2008); none result in lethality. Here we report the most severe disruption of function by any synaptotagmin mutation identified to date.

\section{Materials and Methods}

\section{Site-directed mutagenesis}

Phenylalanine 286 (Fig. 1, $\mathrm{F}^{*}$ ) and isoleucine 420 (Fig. 1, $\mathrm{I}^{*}$ ) of Drosophila synaptotagmin were mutated using PCR. For F286, mutant antisense oligonucleotide CGCCGATCTGGTCGTGCTTCGATTCGCGATCGAAG TCGAAAATGGC was used to incorporate a glutamate residue (syt ${ }^{\mathrm{A}-\mathrm{FE}}$ ), and CGCCGATCTGGTCGTGCTTCGAGTAGCGATCGAAGTCGAAAA TGGC was used to incorporate a tyrosine residue (syt ${ }^{\mathrm{A}-\mathrm{FY}}$ ). For I420, mutant antisense oligonucleotide TGCAGCGGCCGATGGGTTCGGAGGTGCCTTCACGATCGTAGTCCACGACGGTCACAACG was used to incorporate a glutamate residue (syt $\left.{ }^{\mathrm{B}-\mathrm{IE}}\right)$. Mutant PCR products were ligated into otherwise wild-type Drosophila synaptotagmin I cDNA in pBluescript II, sequenced to ensure that the only change introduced by PCR was the desired mutation, and subcloned into a pUAST vector to place the mutant syt under the control of the upstream activating sequence (UAS) promoter (Brand and Perrimon, 1993; Yao and White, 1994).

\section{Generation of mutant transgenic lines}

Drosophila embryos were transfected with the mutant pUAST plasmids as described previously (Paddock et al., 2008) or by Genetic Services. Expression of the transgene was localized to the nervous system using the pan-neuronal promoter elav to drive galactosidase-4 (Gal4) expression, and the Gal4/UAS system was used to amplify expression of the syt transgenes (Brand and Perrimon, 1993; Yao and White, 1994). Because no gender selection was used, a mix of male and female animals were used for all experiments. Lines used included the following: $y w$; syt $t^{\text {null }}$ elavGAL4/CyO, GFP (source of Gal4 to drive transgene expression in the nervous system), $y w ; s y t^{n u l l} / C y O, y+; P\left[U A S\right.$ syt $\left.{ }^{A-F 286 Y}\right]$ lines 3 and 5 $\left(P\left[s y t^{A-F Y}\right]\right.$ lines $), y w ; s y t^{n u l l} / C y O, y+; P\left[U A S s y t^{A-F 286 E}\right]\left(P\left[s y t^{A-F E}\right]\right.$ line $)$, $y w ; s y t^{\text {null }} / C y O, y+; P\left[U A S s y t^{B-I 420 E}\right]$ lines 4 and $6\left(P\left[s y t^{B-I E}\right]\right.$ lines $)$, and $y w ; s y t^{\text {null }} / \mathrm{CyO}, y+; P\left[U A S\right.$ syt $\left.t^{W T}\right]$ (transgenic control, $\left.P\left[s y t^{W T}\right]\right)$. Stan- dard genetic techniques were used to cross the transgenes into the $s y t^{\text {null }}$ background; selected larvae were green fluorescent protein (GFP) negative and y negative without regard to gender. Unless specifically noted, experiments were performed in the syt $t^{\text {null }}$ background to express the transgene in the absence of endogenous synaptotagmin I.

\section{Analysis of dominant-negative}

lethality phenotype

The effect of the syt ${ }^{\mathrm{B}-\mathrm{IE}}$ mutant protein was examined both in the absence and presence of expression from the wild type synaptotagmin gene. Drosophila lines used were: $y w$; syt $t^{\text {null }} e$ lavGAL4/CyO, GFP: $y w ; \quad s y t^{\text {null }} / C y O, \quad y+$; $P\left[U A S s y t^{B-I 42 O E}\right]$ lines $4 \& 6$ : and $y w ; s y t^{n u l l} /$ $C y O, y+; P\left[U A S\right.$ syt $\left.{ }^{W T}\right]$. Parental lines contain the native syt gene on the $\mathrm{CyO}$ balancer chromosome to maintain healthy stocks, and transgene expression is under the control of a UAS promoter that requires Gal4 to promote expression. The following lines were crossed on molasses plates, and progeny were monitored for the ability to hatch: $y w$; syt $t^{\text {null }} / C y O, y+$; $P[U A S s y t] / P[U A S s y t]$ were crossed to $y w ;$ sytnull elavGal4/CyO, GFP; +/+. The four possible progeny are of the following genotypes: $y w$; sytnull/syt $t_{\text {null }}^{\text {elavGal4; } P[U A S s y t] /+\quad \text { (transgenic }}$ syt alone, no $\mathrm{y}+$, no GFP); $y w ; s^{\text {null }} / \mathrm{CyO}$, GFP; $P[U A S s y t] /+$ (native syt alone attributable to CyO and lack of the transgene driver elavGal4, no + , GFP present); $y w$; syt ${ }^{\text {null }}$ elavGal4/CyO, $y+; P[U A S s y t] /+$ (native + transgenic syt attributable to CyO and transgene driver elavGal4, $\mathrm{y}+$, no GFP); and $y w ; C y O, y+/ C y O$, GFP; $P[U A S$ $s y t] /+(\mathrm{y}+$, GFP present). Balancer chromosome homozygotes, $\mathrm{CyO}$, $y+/ C y O, G F P$, are embryonic lethal and do not hatch. $P\left[U A S s y t^{B-I E}\right]$ lines were crossed in parallel with $P\left[U A S s y t^{W T}\right]$ lines.

\section{Immunolabeling and immunoblotting}

Saline used was HL3 [in mM: $5 \mathrm{KCl}, 1.5 \mathrm{CaCl}_{2}, 70 \mathrm{NaCl}, 20 \mathrm{MgCl}_{2}, 10$ $\mathrm{NaCHO}_{3}, 5$ HEPES, 115 sucrose, and 5 trehalose (Stewart et al., 1994)]. Immunolabeling and immunoblotting of third-instar larvae were performed by standard techniques (Paddock et al., 2008) using the anti-synaptotagmin antibody Dsyt-CL1 (Mackler et al., 2002). For immunolabeling of embryos, mutants were dechorionated in $50 \%$ bleach and glued (GLUture; Abbott Laboratories) to Sylgard-coated dishes containing $\mathrm{Ca}^{2+}$-free HL3. The cuticle was perforated and opened along the dorsal midline with a glass needle, and the gut was removed to expose the CNS. After fixation in 4\% paraformaldehyde in PBS, synapses were labeled with either Dsyt-CL1 (diluted 1:200) or an anti-cysteine string protein (CSP) monoclonal antibody (diluted 1:50) (Zinsmaier et al., 1994) overnight at $4^{\circ} \mathrm{C}$. During an overnight incubation at $4^{\circ} \mathrm{C}$, Dsyt-CL1 was labeled with an Alexa Fluor-488 goat-anti-rabbit antibody (diluted 1:500; Invitrogen), whereas CSP was labeled with an Alexa Fluor-488 rabbit anti-mouse antibody (diluted 1:200; Invitrogen).

\section{Electrophysiology}

Third-instar recordings. Evoked and spontaneous excitatory junction potentials [EJPs and miniature EJPs (mEJPs)] were recorded from ventral longitudinal muscle 6 of segments 3 and 4 in HL 3 saline as described previously (Loewen et al., 2001; Mackler and Reist, 2001; Paddock et al., 2008). Briefly, third-instar larvae were dissected in $\mathrm{Ca}^{2+}$-free HL3 to expose the body wall musculature. After changing to HL3 containing 1.5 $\mathrm{mM} \mathrm{Ca}{ }^{2+}$, muscle 6 was impaled with a $10-40 \mathrm{M} \Omega$ electrode filled with a solution of three parts $2 \mathrm{~m}$ potassium citrate to one part $3 \mathrm{~m}$ potassium chloride. Evoked EJPs were generated by stimulating segmental nerves with $1 \mathrm{~ms}$ pulses of $30-50 \mathrm{nA}$ at $0.05 \mathrm{~Hz}$. Intracellular recordings of spontaneous mEJPs were collected and analyzed as described previously (Mackler and Reist, 2001). One-way ANOVA and Tukey range test were used for statistical comparisons. 
Embryonic recordings. To record synaptic currents, Drosophila embryos (22-24 h after egg laying) were dechorionated with bleach and manually dissected as described previously (Featherstone et al., 2009). Embryonic ventral longitudinal muscle 6 from segment 3 or 4 was then whole-cell voltage clamped at $-60 \mathrm{mV}$ in bath solution [containing in mM: $135 \mathrm{NaCl}, 5$ $\mathrm{KCl}, 4 \mathrm{MgCl}_{2}, 1.8 \mathrm{CaCl}_{2}, 72$ sucrose, and 5 $N$-[Tris(hydroxymethyl)methyl]-2-

aminoethanosulfonic acid (TES), pH 7.2], as described previously (Chen et al., 2009). The patch pipette solution contained the following (in $\mathrm{mm}$ ): $120 \mathrm{KCl}, 20 \mathrm{KOH}, 4 \mathrm{MgCl}_{2}, 0.25$ $\mathrm{CaCl}_{2}, 5$ EGTA, 36 sucrose, and 5 TES. Evoked synaptic currents were triggered by $5-10 \mathrm{~V}$ electrical stimulation of the appropriate segmental nerve using a suction electrode filled with bath solution. Data acquisition and analysis were performed using pClamp 10 (Molecular Devices). A Student's $t$ test was used for statistical comparison of syt $t^{\text {null }}$ and $P\left[s y t^{B-I E}\right]$ mutants.

\section{Electron microscopy}

Stage 17 embryos were dissected in ice-cold, $\mathrm{Ca}^{2+}$-free HL3 and transferred immediately to ice-cold primary fixative ( $1 \%$ acrolein and $2.5 \%$ glutaraldehyde in $0.1 \mathrm{M}$ cacodylate buffer) for $1 \mathrm{~h}$. They were postfixed in a reduced osmium solution $(0.5 \%$ osmium tetroxide and $0.8 \%$ potassium ferricyanide in $0.1 \mathrm{M}$ cacodylate buffer) for $1 \mathrm{~h}$, incubated in $2 \%$ aqueous uranyl acetate overnight, embedded in $2 \%$ agar to facilitate handling, dehydrated, and embedded in Embed 812/Araldite (Electron Microscopy Sciences). Sections, at $70 \mathrm{~nm}$, were grid stained in $2 \%$ aqueous uranyl acetate for $15 \mathrm{~min}$, followed by Reynold's lead for 2 min. Random sections through the ventral nerve cord were examined at $30,000 \times$ magnification in the electron microscope.

\section{Co-sedimentation assay}

Co-sedimentation assays were conducted as described previously (Wang et al., 2003). Briefly, synaptotagmin $\mathrm{C}_{2} \mathrm{AB}$ or $\mathrm{C}_{2} \mathrm{~B}$ domains ( $4 \mu \mathrm{m}$ final concentration) were incubated with increasing concentrations of protein free liposomes (PS/PC/PE, 15/55/30\%) for $15 \mathrm{~min}$ at room temperature in the presence of either $1 \mathrm{mM} \mathrm{Ca}^{2+}$ or $0.2 \mathrm{~mm}$ EGTA. The mixtures were then centrifuged at 70,000 rpm for $1 \mathrm{~h}$. The supernatant of each sample was collected, mixed with SDS loading buffer, and boiled for $5 \mathrm{~min}$. Samples were subjected to SDS-PAGE and stained with Coomassie blue.

\section{Co-flotation assay}

As described previously (Gaffaney et al., 2008), PS-free t-SNARE vesicles were mixed with the indicated syt proteins ( $10 \mu \mathrm{M}$ final concentration) in the presence of either $1 \mathrm{mM} \mathrm{Ca}^{2+}$ or $0.2 \mathrm{~mm}$ EGTA at room temperature for $30 \mathrm{~min}$. Samples were mixed with an equal volume of $80 \%$ Accudenz and transferred to centrifuge tubes (Beckman Instruments). Accudenz, at 35,30 , and $0 \%$, was sequentially added to form step gradients. Samples were centrifuged at 55,000 rpm for $105 \mathrm{~min}$, collected at the interface between the 30 and $0 \%$ Accudenz layers, and analyzed by SDS-PAGE.

\section{Glutathione S-transferase-syt pull-down assay}

Glutathione $S$-transferase (GST)-tagged syt proteins $\left(\mathrm{C}_{2} \mathrm{AB}, 3 \mu \mathrm{M} ; \mathrm{C}_{2} \mathrm{~B}, 6\right.$ $\mu \mathrm{M})$ were incubated with Glutatione Sepharose beads (GE Healthcare) for $1 \mathrm{~h}$ in buffer $(20 \mathrm{~mm}$ Tris, $150 \mathrm{~mm} \mathrm{NaCl}$, and $1 \%$ Triton X-100). The mixtures were washed with buffer and then incubated with t-SNARE protein $(3 \mu \mathrm{M})$ in buffer containing either EGTA $(0.2 \mathrm{~mm})$ or Ca (1 mM) for $30 \mathrm{~min}$ at room temperature. The samples were spun down and washed with buffer three times. The pellets were boiled in sample buffer, subjected to SDS-PAGE, and stained with Coomassie blue.
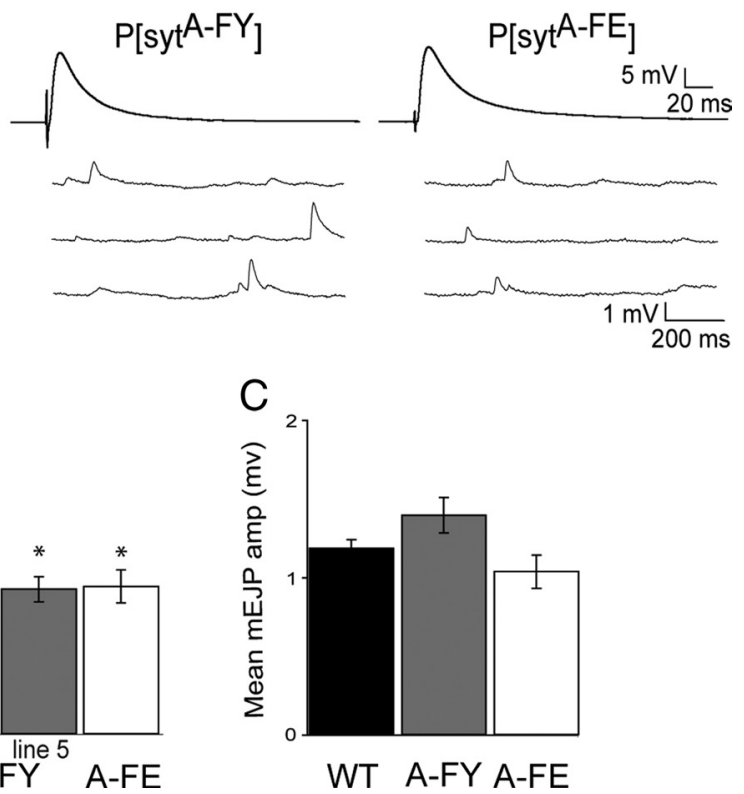

Figure 2. Evoked release is impaired in $C_{2}$ A hydrophobic mutants. $A$, Representative voltage traces recorded from larval muscle ther 6 . Each top trace shows the mean of 30 consecutive evoked responses from the same muscle fiber. The bottom traces show $3 \mathrm{~s}$ of continuous spontaneous recordings. Line 3 shown for $P\left[\right.$ syt $\left.{ }^{A-F Y}\right] . B$, Compared with $P\left[\right.$ syt $\left.{ }^{W T}\right]$, the mean EJP amplitude of $P\left[s y t^{A-F Y}\right]$, lines

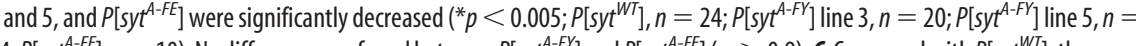
$\left.14 ; P\left[s y t^{A-F E}\right], n=10\right)$. No difference was found between $P\left[\right.$ syt $\left.{ }^{A-F Y}\right]$ and $P\left[\right.$ syt $\left.{ }^{A-F E}\right](p>0.9)$. C, Compared with $P\left[\right.$ syt $\left.{ }^{W T}\right]$, the mean $\mathrm{mEJP}$ amplitude of $P\left[s y \mathrm{t}^{A-F Y}\right]$ (line 3 shown) and $P\left[s y t^{A-F E}\right]$ showed no significant change $(p>0.05)$.

\section{CD spectroscopy}

CD spectra were measured with an AVIV stop flow Circular Dichroism spectropolarimeter at $192-260 \mathrm{~nm}$ using a $1 \mathrm{~mm}$ path-length cell. Samples containing $0.2 \mathrm{mg} / \mathrm{ml}$ of either wild-type or mutant $\mathrm{C}_{2} \mathrm{AB}$ or $\mathrm{C}_{2} \mathrm{~B}$ domains were assayed at $25^{\circ} \mathrm{C}$. For corrections of baseline noise, the signal from a blank run of buffer ( 50 mm sodium phosphate) was subtracted from all the experimental spectra.

\section{Results}

Each $\mathrm{C}_{2}$ domain contains two highly conserved, hydrophobic residues around the rim of the $\mathrm{Ca}^{2+}$-binding pocket that penetrate the bilayer during $\mathrm{Ca}^{2+}$-dependent interactions between synaptotagmin and anionic membranes (Fig. $1 \mathrm{~B}, \mathrm{C}_{2} \mathrm{~A}, \mathrm{~F}^{*}$ and $\mathrm{M}$; $\mathrm{C}_{2} \mathrm{~B}, \mathrm{I}^{*}$ and V) (Bai et al., 2002; Herrick et al., 2006). To determine whether membrane penetration by synaptotagmin is necessary for synaptic function, we mutated a single hydrophobic residue at the very tip of the $\mathrm{Ca}^{2+}$-binding pocket in either the $\mathrm{C}_{2} \mathrm{~A}$ or $\mathrm{C}_{2} \mathrm{~B}$ domain (Fig. 1, $\mathrm{C}_{2} \mathrm{~A}, \mathrm{~F}^{*}$; or $\mathrm{C}_{2} \mathrm{~B}, \mathrm{I}^{*}$ ) that has been shown to penetrate one-sixth of the way into membranes during $\mathrm{Ca}^{2+}$ binding (Bai et al., 2002; Herrick et al., 2006).

\section{$\mathrm{C}_{2} \mathrm{~A}$ membrane penetration facilitates evoked release}

In $\mathrm{C}_{2} \mathrm{~A}$, we mutated the phenylalanine of loop 3 (Fig. 1, $\mathrm{C}_{2} \mathrm{~A}, \mathrm{~F}^{*}$ ) to either tyrosine ( syt $^{\mathrm{A}-\mathrm{FY}}$ ) or glutamic acid ( syt $\left.^{\mathrm{A}-\mathrm{FE}}\right)$. The syt ${ }^{\mathrm{A}-\mathrm{FY}}$ mutation maintains the general structure of the side chain but disrupts the hydrophobicity, whereas the negative charge of the syt $^{\mathrm{A}-\mathrm{FE}}$ mutation disrupts hydrophobicity and repels the head groups of anionic phospholipids. To indicate their transgenic origin, we will call the mutants $P\left[s y t^{A-F Y}\right]$ and $P\left[s y t^{A-F E}\right]$ and the transgenic controls $P\left[s y t^{W T}\right]$. Because these mutants were viable, all $\mathrm{C}_{2} \mathrm{~A}$ experiments were performed on third instars in the absence of the native protein.

$\mathrm{Ca}^{2+}$-evoked neurotransmitter release was decreased to $63 \%$ of control in both $P\left[s y t^{A-F Y}\right]$ and $P\left[s y t^{A-F E}\right]$ mutants (Fig. $2 A, B)$. Because each of the $\mathrm{C}_{2} \mathrm{~A}$ mutants are independent 


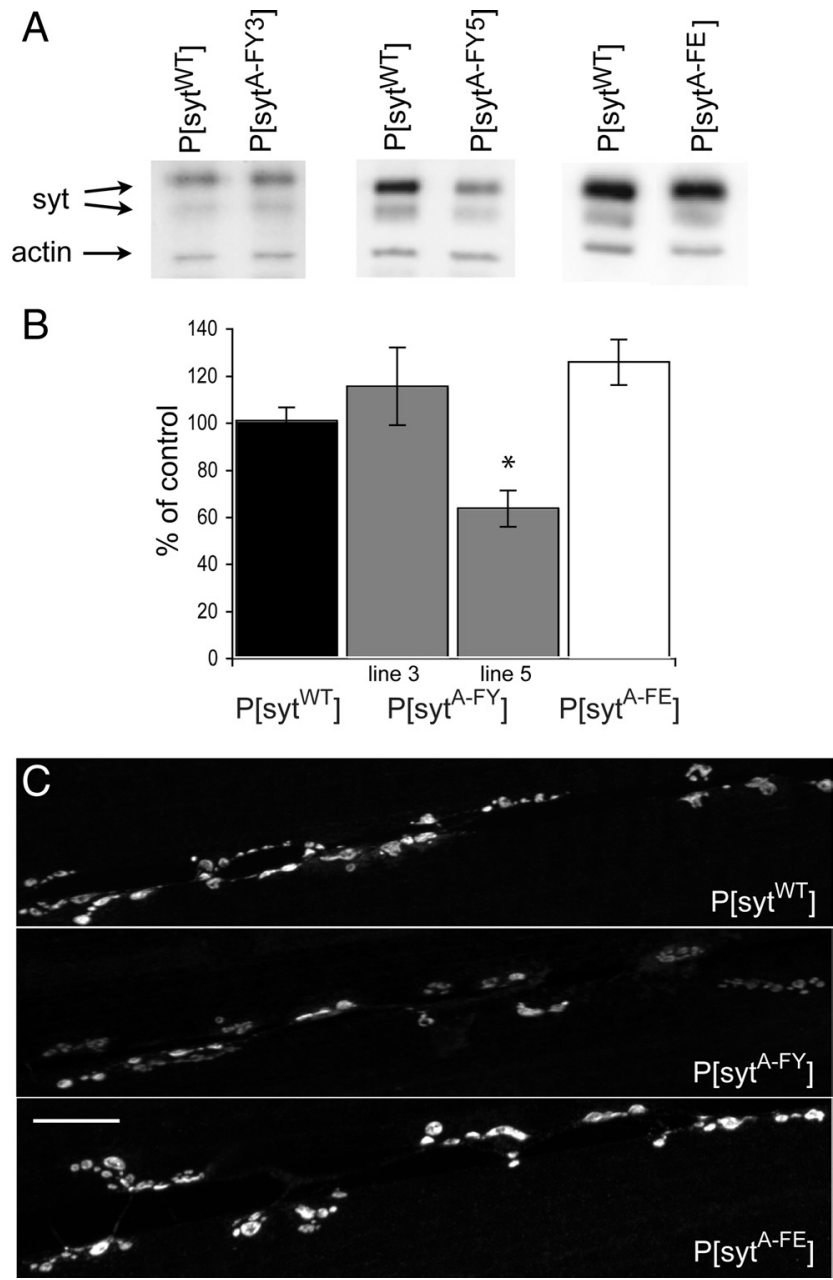

Figure 3. The $C_{2} A$ hydrophobic mutations do not disrupt synaptotagmin expression or targeting. $\boldsymbol{A}$, Representative Western blots from $P\left[\right.$ syt $\left.t^{A-F Y}\right]$ line 3 , line 5 , and $P\left[s y t^{A-F E}\right]$ and their $P\left[\right.$ syt $\left.^{W T}\right]$ controls. $\boldsymbol{B}, P\left[\right.$ syt $\left.^{A-F Y}\right]$ line $5(n=17)$ expressed less transgenic protein than $P\left[s y t^{W T}\right]$ $(n=28)$ and the other two $C_{2}$ A mutants $\left(P\left[\right.\right.$ syt $\left.t^{A-F Y}\right]$ line $3, n=7 ; P\left[\right.$ syt $\left.\left.t^{A-F E}\right], n=11 ; p<0.001\right)$. C, Transgenic synaptotagmin was localized to synaptic sites in all lines (line 5 shown for $P\left[\right.$ syt $\left.\left.^{A-F Y}\right]\right)$. Scale bar, $20 \mu \mathrm{m}$.

transgenic lines, the random insertion site of the transgene does not contribute to the decrease in evoked release. The finding that the mean amplitude of spontaneous release events (mEJP) is unchanged (Fig. 2C) demonstrates that the mutations do not disrupt either vesicle filling or responsiveness of the postsynaptic membrane. Protein misexpression also cannot account for the decrease in evoked release. Although one of the $\mathrm{C}_{2} \mathrm{~A}$ hydrophobic mutants had less transgene expression (Fig. $3 A, B$ ), all three lines provided similar levels of synaptotagmin function during evoked transmitter release (Fig. $2 B$ ). In addition, no difference in synaptotagmin localization to synaptic sites was observed (Fig. 3C). Thus, the decrease in evoked transmitter release in these mutants is specific for the mutation. Interestingly, despite the difference in charge between tyrosine (polar but neutral) and glutamic acid (negatively charged), no difference in the amplitude of evoked release was observed between the $P\left[s y t^{A-F Y}\right]$ or $P\left[s y t^{A-F E}\right] \mathrm{mu}-$ tants (Fig. $2 B$ ), suggesting that disruption of penetration by $\mathrm{C}_{2} \mathrm{~A}$ into the hydrophobic core of the presynaptic membrane, regardless of electrostatic effects, causes the impairment of synaptic transmission.
Table 1. The $C_{2} B$ hydrophobic mutant results in embryonic lethality

\begin{tabular}{rlll}
\hline Line & Transgenic syt alone (\%) & Native syt alone (\%) & Native + transgenic syt (\%) \\
\hline$P\left[\right.$ syt $\left.^{B-I E}\right]$ & & & \\
Line 4 & 0 & 100 & 0 \\
Line 6 & 0 & 100 & 0 \\
$P\left[\right.$ syt $\left.^{W T}\right]$ & 34.1 & 34.8 & 31.1 \\
\hline
\end{tabular}

Progeny are expressed as a percentage of the total larvae that hatched. Total larvae counted per genotype were as follows: $P\left[\right.$ syt $\left.t^{-1 / E}\right]$ line 4, 265 larvae; line 6, 237 larvae; $P\left[\right.$ syt $\left.t^{W T}\right], 1178$ larvae.

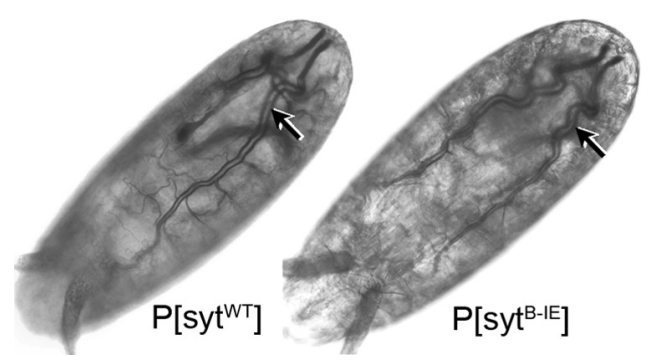

Figure 4. $\quad$ syt ${ }^{\mathrm{B}-\mathrm{IE}}$ mutant embryos complete embryogenesis and exhibit gross morphology indistinguishable from wild-type embryos. Like controls, $P\left[\right.$ syt $\left.{ }^{B-I E}\right]$ mutants were able to develop through stage 17, as demonstrated by the development of trachea (arrows).

\section{$\mathrm{C}_{2} \mathrm{~B}$ membrane penetration is essential for synaptotagmin function}

To assess the physiological significance of the homologous hydrophobic residue in $\mathrm{C}_{2} \mathrm{~B}$, we mutated the isoleucine of loop three (Fig. 1, $\mathrm{C}_{2} \mathrm{~B}, \mathrm{I}^{\star}$ ) to glutamic acid $\left(\right.$ syt $^{\mathrm{B}-\mathrm{IE}}$ ). This introduction of negative charge should both prevent $\mathrm{Ca}^{2+}$-dependent membrane penetration and repel the head groups of the anionic phospholipids. Expression of the syt ${ }^{\mathrm{B}-\mathrm{IE}}$ protein in the absence of native synaptotagmin resulted in embryonic lethality (Table 1, compare $P\left[s y t^{B-I E}\right]$ to $P\left[s y t^{W T}\right]$, transgenic syt alone). The embryos complete embryogenesis (Fig. 4) but fail to hatch. When manually removed from the egg case, the embryos are virtually immobile. There are microscopic movements within the body wall musculature, but these generally are insufficient to displace the embryo and all visible movement stops within hours (our unpublished observation). The only other synaptotagmin mutation to date that causes embryonic lethality is the $P\left[s y t^{B-D 1,2 N}\right]$ mutant in which $\mathrm{Ca}^{2+}$ binding by the $\mathrm{C}_{2} \mathrm{~B}$ domain has been blocked by mutating two of the aspartate residues (Fig. $1 \mathrm{~B}, \mathrm{C}_{2} \mathrm{~B}$, $\mathrm{D}_{1}$ and $\mathrm{D}_{2}$ ) required for coordinating calcium (Mackler et al., 2002). Thus, this single hydrophobic residue at the tip of the $C_{2} B$ $\mathrm{Ca}^{2+}$-binding pocket is the first putative effector residue to be as critical to the organism as the $\mathrm{C}_{2} \mathrm{~B} \mathrm{Ca}^{2+}$-binding residues, suggesting that membrane penetration by the $\mathrm{C}_{2} \mathrm{~B}$ domain is required in vivo.

The syt ${ }^{\mathrm{B}-\mathrm{IE}}$ mutation directly causes the embryonic lethality without disrupting synaptic vesicle biogenesis. Because lethality was observed in multiple independent lines (Table 1, $P\left[s y t^{B-I E}\right]$ line 4 and line 6 , transgenic syt alone), it cannot be caused by the random insertion of the mutant transgene. Similar levels of transgenic protein are expressed in mutant and control embryos (Fig. $5 A, P\left[s y t^{W T}\right]$ vs $P\left[s y t^{B-I E}\right]$, line 6 shown), so the deficit is not attributable to insufficient transgene expression. Although the absence of synaptotagmin results in a dramatic depletion of synaptic vesicles (Jorgensen et al., 1995; Reist et al., 1998; Loewen et al., 2006a), the syt ${ }^{\mathrm{B}-\mathrm{IE}}$ mutation does not. Ultrastructural examination reveals abundant small clear vesicles within the synaptic neuropil (Fig. 5B). In addition, immunolabeling of the mutant embryos for a synaptic vesicle marker, CSP (Mastrogiacomo et 
al., 1994), demonstrates that the overall population of synaptic vesicles in the neuropil is correctly localized to synaptic regions (Fig. 5C), indicating that this mutation does not disrupt the formation or targeting of synaptic vesicles. Finally, the syt ${ }^{\mathrm{B}-\mathrm{IE}}$ mutant protein is also appropriately localized to synaptic sites. In the central nervous system, syt ${ }^{\mathrm{B}-\mathrm{IE}}$ staining is appropriately localized to the synaptic neuropil (Fig. 5D). In the peripheral nervous system, syt ${ }^{\mathrm{B}-\mathrm{IE}}$ staining is appropriately localized to the neuromuscular junction (Fig. 5E), demonstrating that this mutation does not disrupt synaptotagmin targeting. Indeed, because $s y t^{\text {null }}$ mutants can survive through to adulthood (Loewen et al., 2001), the embryonic lethality demonstrates that the syt ${ }^{\mathrm{B}-\mathrm{IE}}$ transgene is expressed and is dominantly inhibiting function.

The nearly complete absence of locomotion in the syt ${ }^{\mathrm{B}-\mathrm{IE}}$ mutants indicates that the lethality results from an inability to move out of the embryonic egg casing. However, this is an indirect assessment of synaptic activity. To directly test the impact of the syt ${ }^{\mathrm{B}-\mathrm{IE}}$ mutation on synaptic transmission, excitatory junction currents (EJCs) were recorded from $P\left[s y t^{B-I E}\right] \mathrm{mu}-$ tant, syt $t^{\text {null }}$ mutant, and $P\left[s y t^{W T}\right]$ transgenic control embryos. Our recordings are not directly comparable with previous reports (Broadie et al., 1994; Mackler and Reist, 2001; Yoshihara and Littleton, 2002) because of differences in the positive control ( $+/+$ vs $\left.-/-; P\left[s y t^{W T}\right]\right)$ and/or saline (differing concentrations of divalent cations) used. As shown in Figure 6, the amplitude of evoked transmitter release in $P\left[s y t^{B-I E}\right]$ mutants was $17.5 \%$ of the transgenic $P\left[s y t^{W T}\right]$ control. However, most importantly, expression of the syt ${ }^{\mathrm{B}-\mathrm{IE}}$ protein was worse than no synaptotagmin I expression at all; the EJC amplitude in $P\left[s y t^{B-I E}\right]$ mutants was only $50 \%$ of that seen in $s y t^{\text {null }}$ mutants (Fig. 6) $(p<0.02)$. Thus, the syt ${ }^{\mathrm{B}-\mathrm{IE}}$ mutant is the only effector interaction mutation to date that results in a more severe inhibition of synaptic transmission than the syt $t^{\text {null }}$ mutation. The only other synaptotagmin mutants to exhibit such an effect are $\mathrm{C}_{2} \mathrm{~B} \mathrm{Ca}^{2+}$-binding motif mutants (Mackler et al., 2002).

Proper folding of the syt ${ }^{\mathrm{B}-\mathrm{IE}}$ mutant protein was verified by $\mathrm{CD}$ spectroscopy. Figure $7 \mathrm{~A}$ demonstrates that this mutation does not alter the spectra for either the $\mathrm{C}_{2} \mathrm{AB}$ (left panel) or the $\mathrm{C}_{2} \mathrm{~B}$ (right panel) domains. But does mutation of this $\mathrm{C}_{2} \mathrm{~B}$ hydrophobic residue primarily block interactions with negatively charged membranes or does it inhibit interactions with SNAREs? Mutation of all four of the hydrophobic residues that penetrate membranes (Fig. $1 \mathrm{~B}, \mathrm{C}_{2} \mathrm{~A}, \mathrm{~F}^{*}$; $\mathrm{M}, \mathrm{C}_{2} \mathrm{~B}, \mathrm{I}^{*}$ and $\mathrm{V}$, mutated to alanines; $\mathrm{C}_{2} \mathrm{AB}^{4 \mathrm{~A}}$ ) dramatically inhibited interactions with negatively charged phospholipids (Lynch et al., 2008). However, the effect of this quadruple mutation on $\mathrm{C}_{2} \mathrm{AB}$ interactions with SNARE proteins has been inconsistent. In one study, $\mathrm{C}_{2} \mathrm{AB}$ binding to t-SNAREs was not effected by the $\mathrm{C}_{2} \mathrm{AB}^{4 \mathrm{~A}}$ mutation (Lynch et al., 2008), indicating that even this quadruple mutation was properly folded and specific for $\mathrm{Ca}^{2+}$-dependent
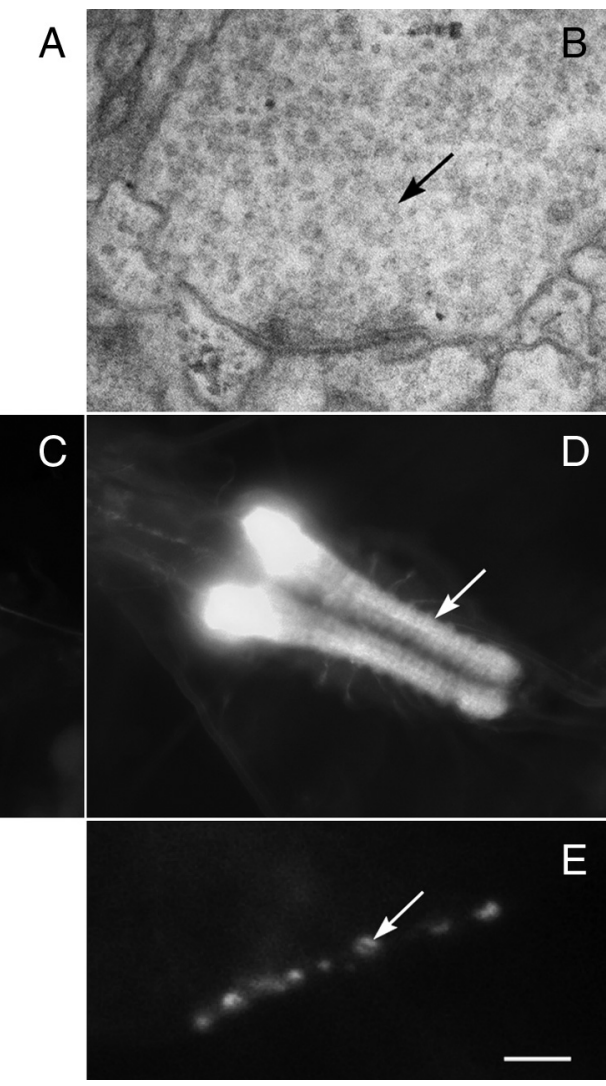

$D$

Figure 5. The $C_{2} B$ hydrophobic mutation does not disrupt synaptic vesicle localization, synaptotagmin expression, or synaptolot was probed with an anti-actin antibody to confirm equal loading. $B$, A representative nerve terminal within the neuropil of a was also correctly localized to the neuropil ( $\boldsymbol{D}$, white arrow) in the CNS, as well as to neuromuscular junctions $(\boldsymbol{E}$, white arrow) in the peripheral nervous system. $P\left[\right.$ syt $\left.^{B-I E}\right]$ line 6 is shown. Scale bar: $\boldsymbol{B}, 180 \mathrm{~nm} ; \boldsymbol{C}, \boldsymbol{D}, 40 \mu \mathrm{m} ; \boldsymbol{E}, 5 \mu \mathrm{m}$.

phospholipid interactions. However, in another study, this same quadruple mutation resulted in a partial decrease in binding to t-SNAREs (Hui et al., 2009).

To determine the effector interactions disrupted by our single syt ${ }^{\mathrm{B}-\mathrm{IE}}$ mutation, we conducted biochemical interaction assays using $\mathrm{C}_{2} \mathrm{AB}$ or isolated $\mathrm{C}_{2} \mathrm{~B}$ domains. To determine the effect of the syt ${ }^{\mathrm{B}-\mathrm{IE}}$ mutation on interactions with membranes, we measured the ability of protein-free, negatively charged liposomes (containing $15 \% \mathrm{PS}$ ) to bind $\mathrm{C}_{2} \mathrm{AB}$ domains. The syt ${ }^{\mathrm{B}-\mathrm{IE}}$ mutation caused a marked decrease in $\mathrm{Ca}^{2+}$-dependent interactions of $\mathrm{C}_{2} \mathrm{AB}$ with PS liposomes, but significant binding remained (Fig. $7 B)$. However, interactions with membranes may be mediated by both the $\mathrm{C}_{2} \mathrm{~A}$ and the $\mathrm{C}_{2} \mathrm{~B}$ domains (Bai et al., 2002; Shin et al., 2003; Rhee et al., 2005). To determine whether any membrane binding activity can be mediated by the mutated $\mathrm{C}_{2} \mathrm{~B}$ domain, we measured the ability of isolated $\mathrm{C}_{2} \mathrm{~B}$ domains to bind PS liposomes. As shown in Figure $7 B$, the syt ${ }^{\mathrm{B}-\mathrm{IE}}$ mutation abolished $\mathrm{Ca}^{2+}$-dependent interactions with negatively charged liposomes. Thus, the complete block of membrane interactions by the $\mathrm{C}_{2} \mathrm{~B}$ domain could account for the severe inhibition of evoked release and lethality seen in these mutants.

To determine whether the syt ${ }^{\mathrm{B}-\mathrm{IE}}$ mutation also impacted interactions with t-SNAREs in the absence of membranes, we measured the ability of GST-C $\mathrm{C}_{2} \mathrm{AB}$ or GST- $\mathrm{C}_{2} \mathrm{~B}$ fusion proteins to bind to full-length t-SNAREs solubilized in detergent (Fig. $8 \mathrm{~A}$ ). 

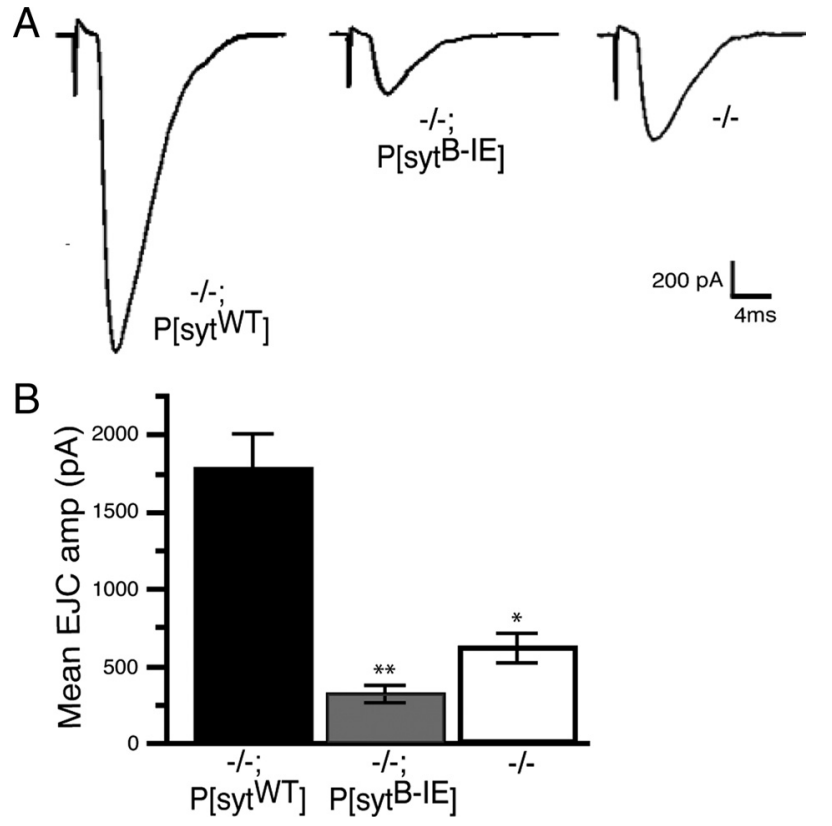

Figure 6. The $C_{2} B$ hydrophobic mutation inhibits evoked transmitter release more severely than the syt ${ }^{\text {null }}$ mutation. $A$, Representative current traces recorded from embryonic muscle fiber 6. $\boldsymbol{B}$, The mean EJC amplitude in transgenic control embryos was $1782 \pm 224 \mathrm{pA}(-/-$; $P\left[\right.$ syt $\left.\left.^{W T}\right], n=8\right)$, in $P\left[\right.$ sytt $\left.t^{B-I F}\right]$ mutant embryos was $312.2 \pm 62.6 \mathrm{pA}\left(-/-; P\left[\right.\right.$ syt $\left.\left.t^{B-I E}\right], n=8\right)$, and in syt $t^{\text {null }}$ mutants was $625.2 \pm 89.0 \mathrm{pA}(-/-, n=11)$. Evoked release in $P\left[\right.$ syt $\left.{ }^{B-I E}\right]$ was significantly less than in syt $t^{\text {null }}$ mutants $\left({ }^{*}\right.$ vs $^{* *}, p<0.02$ ).

The syt ${ }^{\mathrm{B}-\mathrm{IE}}$ mutation decreased interactions with t-SNAREs, especially in the absence of $\mathrm{Ca}^{2+} . \mathrm{Ca}^{2+}$ increased t-SNARE binding to $\mathrm{C}_{2} \mathrm{AB}$ domains by 0.2 units or 2.4 -fold in wild type and by 0.112 units or 4.5 -fold in syt ${ }^{\mathrm{B}-\mathrm{IE}}$ mutants. When isolated $\mathrm{C}_{2} \mathrm{~B}$ domains were used, $\mathrm{Ca}^{2+}$ increased t-SNARE binding by 0.116 units or 2.5-fold in wild type and by 0.105 units or 4.9-fold in syt ${ }^{\mathrm{B}-\mathrm{IE}}$ mutants. The effect on $\mathrm{Ca}^{2+}$-dependent t-SNARE binding to $\mathrm{C}_{2} \mathrm{~B}$ is minimal, yet the inhibition of $\mathrm{Ca}^{2+}$-dependent phospholipid binding to $\mathrm{C}_{2} \mathrm{~B}$ is complete. Thus, the lethality seen in these mutants correlates best with the disruption in phospholipid interactions. However, a contribution attributable to altered t-SNARE binding cannot be definitively excluded. In addition, the finding that the $\mathrm{Ca}^{2+}$-dependent increase in t-SNARE binding is essentially intact in the $\mathrm{C}_{2} \mathrm{~B}$ hydrophobic mutant suggests that, if this residue mediates any direct interaction with t-SNAREs (but see below), it likely occurs during the docking or priming of vesicles before $\mathrm{Ca}^{2+}$ influx.

Interestingly, the $\mathrm{Ca}^{2+}$-dependent interaction between $\mathrm{C}_{2} \mathrm{~B}$ and membrane-embedded t-SNAREs requires this hydrophobic residue in $\mathrm{C}_{2} \mathrm{~B}$. When $\mathrm{t}$-SNAREs are embedded in net neutral liposomes [PC/PE to prevent direct electrostatic interactions with synaptotagmin (Gaffaney et al., 2008)], $\mathrm{Ca}^{2+}$ caused an approximate twofold increase in binding (Fig. $8 \mathrm{~B}, \mathrm{C}_{2} \mathrm{~B} ; \mathrm{C}, \mathrm{C}_{2} \mathrm{AB}$ ). The syt ${ }^{\mathrm{B}-\mathrm{IE}}$ mutation partially blocked the $\mathrm{C}_{2} \mathrm{AB}$ (Fig. $8 C, \mathrm{C}_{2} \mathrm{AB}$, I420E) and completely blocked the $\mathrm{C}_{2} \mathrm{~B} \mathrm{Ca}^{2+}$-dependent t-SNARE/ membrane interaction (Fig. $8 \mathrm{~B}, \mathrm{C}_{2} \mathrm{~B}, \mathrm{I} 420 \mathrm{E}$ ), similar to the finding for binding to PS-containing liposomes (Fig. $7 B$ ). Thus, the presence of membrane altered the interactions with t-SNAREs. The finding that $\mathrm{Ca}^{2+}$-dependent $\mathrm{t}$-SNARE interactions mediated by $\mathrm{C}_{2} \mathrm{~B}$ were intact in the mutants in the absence of membrane but are abolished in the presence of membrane suggests that the interaction shown in Figure $8 B$ is actually membrane dependent. In addition, because the $\mathrm{Ca}^{2+}$-independent interaction with t-SNAREs that are embedded in membranes (as they are in vivo) is intact in the mutant (Fig. $8 B, C$ ), this hydrophobic residue is unlikely to mediate a direct interaction with t-SNAREs during docking or priming. The simplest interpretation is that this t-SNARE interaction may require membrane penetration by the tip of the $\mathrm{C}_{2} \mathrm{~B}$ domain. Together, the biochemistry supports the hypothesis that $\mathrm{Ca}^{2+}$-dependent membrane penetration by this hydrophobic residue on the tip of the $\mathrm{C}_{2} \mathrm{~B}$ domain is the essential effector interaction that couples $\mathrm{Ca}^{2+}$ binding by synaptotagmin with vesicle fusion.

\section{Expression of the $P\left[s y t^{\mathrm{B}-\mathrm{IE}}\right]$ transgene has a dominant-negative effect}

To analyze the inhibitory effect of the syt ${ }^{\mathrm{B}-\mathrm{IE}}$ protein, we expressed the transgenic mutant protein in the presence of native synaptotagmin. When transgene expression rescues synaptotagmin function, the hatching progeny are approximately evenly distributed between the "transgenic syt alone," "native syt alone," and "native + transgenic syt" genotypes (see Table 1, $P\left[s y t^{W T}\right]$ and methods). If transgene expression did not enhance viability in the absence of native synaptotagmin yet did not impact the function of native synaptotagmin, we would expect few progeny in the transgenic syt alone genotype [syt $t^{\text {null }}$ mutants are weakly viable (Loewen et al., 2001)] and an approximately equal distribution of progeny between the native syt alone and native + transgenic syt genotypes (i.e., no dominant-negative effect). When more progeny are able to hatch of the native syt alone genotype than of the native + transgenic syt genotype (Table 1 , $\left.P\left[s y t^{B-I E}\right]\right)$, this indicates that the transgene is dominantly inhibiting the function of the native protein. Remarkably, expression of syt ${ }^{\mathrm{B}-\mathrm{IE}}$ mutant protein was embryonic lethal even in the presence of native synaptotagmin (Table 1 , compare $P\left[s y t^{B-I E}\right]$ to $P\left[s y t^{W T}\right]$, native + transgenic syt). Previously, the only synaptotagmin mutations documented to result in a dominant-negative effect were tandem point mutations within the $\mathrm{C}_{2} \mathrm{~B} \mathrm{Ca}^{2+}$. binding motif [ syt $^{\mathrm{B}-\mathrm{D} 1,2 \mathrm{~N}}$ and syt ${ }^{\mathrm{B}-\mathrm{D} 3,4 \mathrm{~N}}$ (Mackler et al., 2002)]. However, in the presence of wild-type synaptotagmin, some of these tandem mutants were able to hatch and remained viable through the third-instar stage, although they did impair synaptic transmission. Thus, mutation of the hydrophobic residue at the tip of the $\mathrm{C}_{2} \mathrm{~B} \mathrm{Ca}^{2+}$-binding pocket is the most severe mutation of synaptotagmin function to date.

\section{Discussion}

In our model for synaptotagmin function (Fig. 9), we propose that presynaptic membrane penetration by $\mathrm{C}_{2} \mathrm{~B}$ is the critical effector interaction for coupling $\mathrm{Ca}^{2+}$ binding by synaptotagmin with evoked transmitter release at the synapse. In agreement with models of SNARE-mediated fusion (Weber et al., 1998; Lang and Jahn, 2008; Rizo and Rosenmund, 2008), we propose that multiple synaptotagmin/SNARE complexes are localized in a ring around the site of synaptic vesicle/presynaptic membrane apposition (Fig. 9A,D). Before $\mathrm{Ca}^{2+}$ influx, interactions between the $\mathrm{C}_{2} \mathrm{~B}$ polylysine motif (Fig. $9 \mathrm{~B}$, yellow space-filled residues) and SNARE complexes help hold the vesicle in a docked/primed state (Rickman et al., 2004; Loewen et al., 2006b), whereas the negative charge of the $\mathrm{Ca}^{2+}$-binding pockets (Fig. $9 A$, single - signs; $B$, cluster of - signs) repulses the negatively charged presynaptic membrane. During $\mathrm{Ca}^{2+}$ binding, the negative charge of the pockets is neutralized, which initiates the electrostatic switch (Davletov et al., 1998; Ubach et al., 1998; Zhang et al., 2002): a dramatic shift in the electrostatic potential of each $\mathrm{C}_{2}$ domain. This increase in positive charge could strengthen (Loewen et al., 2006b), or initiate new (Lynch et al., 2007), interactions with 
negatively charged regions of the SNAREs and permit an electrostatic interaction between the positively charged residues at the tips of the $\mathrm{Ca}^{2+}$-binding pockets (Fig. 9, blue space-filled residues, + ) and the negatively charged presynaptic membrane (Fernández-Chacón et al., 2001; Wang et al., 2003; Paddock et al., 2008). $\mathrm{Ca}^{2+}$ binding would also permit the hydrophobic residues at the tips of each $\mathrm{C}_{2}$ domain (Fig. 9, gray space-filled residues) to penetrate into the hydrophobic core of the presynaptic membrane (Bai et al., 2002; Herrick et al., 2006), thereby inducing positive curvature in this membrane (Fig. 9C) (Martens et al., 2007; Hui et al., 2009). Membrane penetration would assist SNARE-mediated fusion by destabilizing the presynaptic membrane and bulging it toward the vesicle (Fig. 9D, large gray ovals, arrows) in a ring around the SNARE complex transmembrane domains (Fig. 9D, small gray circles, arrowheads).

Our model can account for the effects of synaptotagmin mutations seen at synapses. First, we will consider mutations that do not have a dominant inhibitory effect. Mutation of the $\mathrm{C}_{2} \mathrm{~B}$ polylysine motif (Fig. $9 B, C$, yellow space-filled residues) results in only a $\sim 50 \%$ decrease in evoked transmitter release (Mackler and Reist, 2001; Li et al., 2006). Thus, the synaptic vesicle docking/ priming function of this motif facilitates release but is not essential; the $\mathrm{Ca}^{2+}$-binding pockets remain intact and can still penetrate the presynaptic membrane. Mutation of the positively charged residue at the tip of each $\mathrm{Ca}^{2+}$-binding pocket (Figs. 1, $\oplus$; 9, blue space-filled residues, + ) results in a $\sim 50-$ $80 \%$ decrease of evoked transmitter release (Fernández-Chacón et al., 2001; Wang et al., 2003; Paddock et al., 2008). This decrease in function would result from a decrease in the electrostatic attraction of the presynaptic membrane, likely leading to the hydrophobic residues penetrating the membrane less deeply (Herrick et al., 2006). Mutation of the $\mathrm{C}_{2} \mathrm{~A}$ hydrophobic residue, syt ${ }^{\mathrm{A}-\mathrm{FY}}$ or syt $^{\mathrm{A}-\mathrm{FE}}$, results in a $\sim 50 \%$ decrease in evoked transmitter release (Fig. $2 B$ ), indicating that membrane penetration by the $\mathrm{C}_{2} \mathrm{~A}$ domain improves the efficacy of $\mathrm{Ca}^{2+}$. triggered vesicle fusion but, like the other mutants discussed above, it is not required.

Mutations that disrupt interactions with the SNARE complex provide variable results. A mutation that impairs both $\mathrm{Ca}^{2+}$-dependent and $\mathrm{Ca}^{2+}$-independent SNARE interactions (R398A) by $\sim 50 \%$ also impairs the ability of the $\mathrm{C}_{2} \mathrm{AB}$ domain to stimulate SNARE-mediated liposome fusion in vitro by $\sim 35 \%$ (Gaffaney et al., 2008), indicating that this synaptotagmin interaction with the SNARE com-
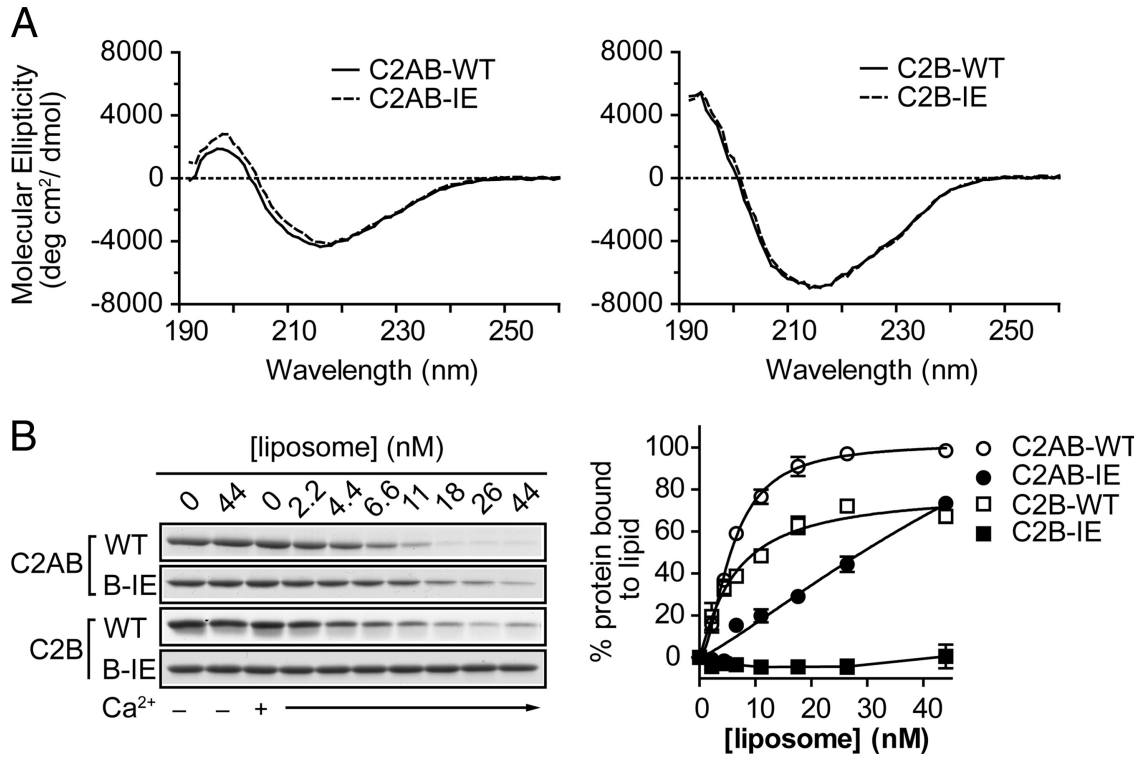

Figure 7. The syt ${ }^{B-1 E}$ mutation abolishes $C_{a}{ }^{2+}$-dependent, $C_{2} B$ interactions with membranes. $A, C_{2} A B$ or $C_{2} B$ domains with the syt ${ }^{B-I E}$ mutation are correctly folded. The $C D$ spectra of the mutant domains ( $C_{2} A B-I E$ and $\left.C_{2} B-I E\right)$ did not show significant changes compared with wild type ( $C_{2} A B-W T$ and $C_{2} B-W T$, respectively). $B$, The syt ${ }^{B-1 E}$ mutation abolishes the ability of the $C_{2} B$ domain to bind negatively charged liposomes. Left, $A$ representative co-sedimentation assay; right, graph of three experiments. In the absence of $\mathrm{Ca}^{2+}, C_{2} \mathrm{AB}$ and $\mathrm{C}_{2} B$ domains do not bind to liposomes containing $15 \%$ PS and thus remain in solution (left, - , WT and $B-I E)$. In the presence of $1 \mathrm{~mm} \mathrm{Ca}{ }^{2+}$, increasing concentrations of liposomes bind increasing amounts of control $C_{2} A B$ or $C_{2} B$ domains $\left(C_{2} A B-W T\right.$ and $\left.C_{2} B-W T\right)$. The syt ${ }^{B-I E}$ mutation impairs this interaction with $C_{2} A B\left(C_{2} A B-I E\right)$ but abolishes the interaction with the isolated $C_{2} B$ domain $\left(C_{2} B-I E\right)$.
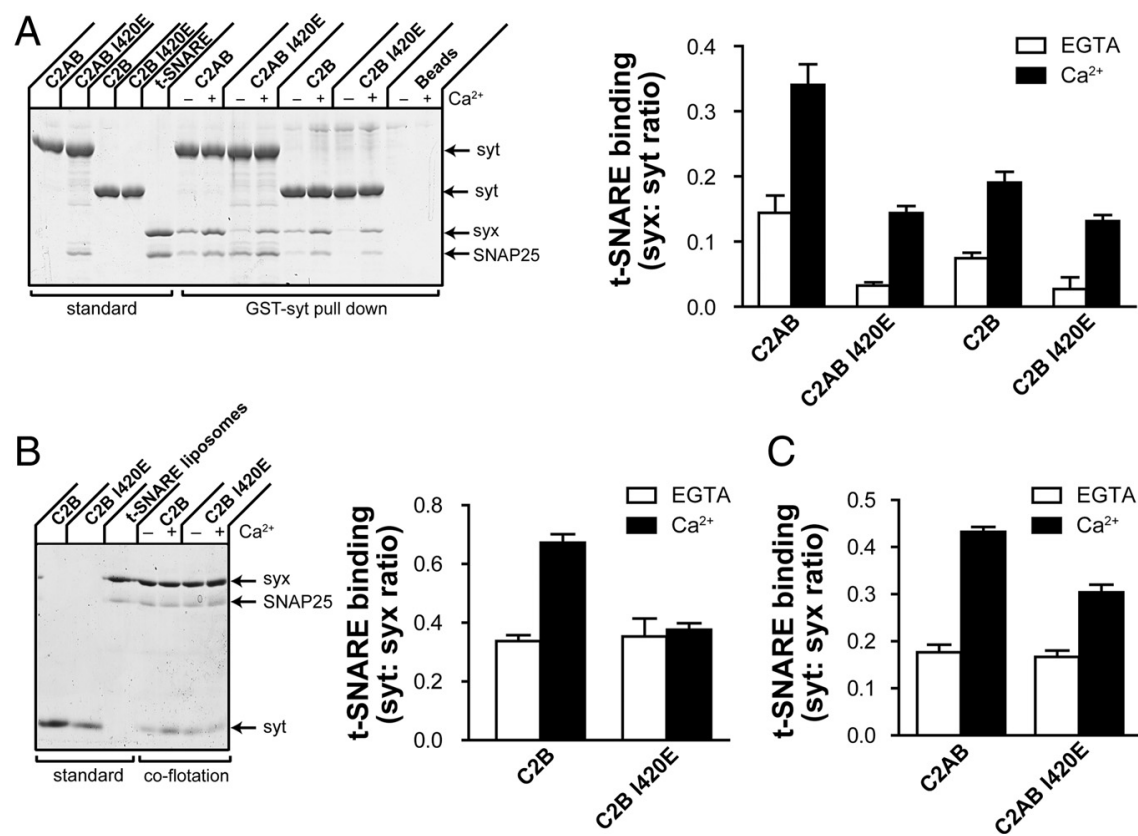

Figure 8. Direct, $\mathrm{Ca}^{2+}$-dependent $\mathrm{C}_{2} \mathrm{~B}$ interactions with $\mathrm{t}-\mathrm{SNAREs}$ are intact in the syt ${ }^{\mathrm{B}-\mathrm{EE}}$ mutation. $\boldsymbol{A}$, The syt ${ }^{\mathrm{B}-\mathrm{IE}}$ mutation does not inhibit $\mathrm{Ca}^{2+}$-dependent interactions with solubilized t-SNAREs. Left, A representative GST-syt pull-down assay; right, histogram of three experiments. The $\mathrm{Ca}^{2+}$-dependent increase in t-SNARE interactions (black bars relative to white bars) is not disrupted by the syt ${ }^{B-1 E}$ mutation. $C^{2+}{ }^{2+}$-independent $t$-SNARE interactions are decreased (white bars, $C_{2} A B$ vs $C_{2} A B$ I420E and $C_{2} B$ vs $C_{2} B$ 1420E). $B$, The syt ${ }^{B-1 E}$ mutation abolishes $C^{2+}{ }^{2+}$-dependent $C_{2} B$ interactions with membrane-embedded t-SNAREs. Left, $A$ representative co-floatation assay; right, histogram of four experiments. The syt ${ }^{B-E}$ mutation does not alter the amount of $C_{2} B$ domain that binds to PS-free, t-SNARE vesicles (t-SNARE) in the absence of $\mathrm{Ca}^{2+}\left(-\right.$, left; EGTA, right). However, the syt ${ }^{\mathrm{B}-\mathrm{IE}}$ mutation abolishes the increase in t-SNARE vesicles binding induced by $1 \mathrm{~mm} \mathrm{Ca}^{2+}\left(+\right.$, left; $\mathrm{Ca}^{2+}$, right; $\left.p<0.05\right)$. C, The syt ${ }^{\mathrm{B}-\mathrm{IE}}$ mutation impairs $C_{2} A B$ interactions with membrane-embedded t-SNAREs. Again, the syt ${ }^{B-E}$ mutation does not alter the amount of $C_{2} A B$ domain that binds to PS-free, $t-S N A R E$ vesicles in the absence of $\mathrm{Ca}^{2+}$ (EGTA, white bars). In the presence of $1 \mathrm{~mm} \mathrm{Ca}^{2+}$ $\left(\mathrm{Ca}^{2+}\right.$, black bars), the t-SNARE vesicles bind $70 \%$ of wild-type levels of $\mathrm{C}_{2} \mathrm{AB}$ domain when the syt ${ }^{\mathrm{B}-\mathrm{IE}}$ mutation is present $(p<$ $0.001 ; n=6)$. 


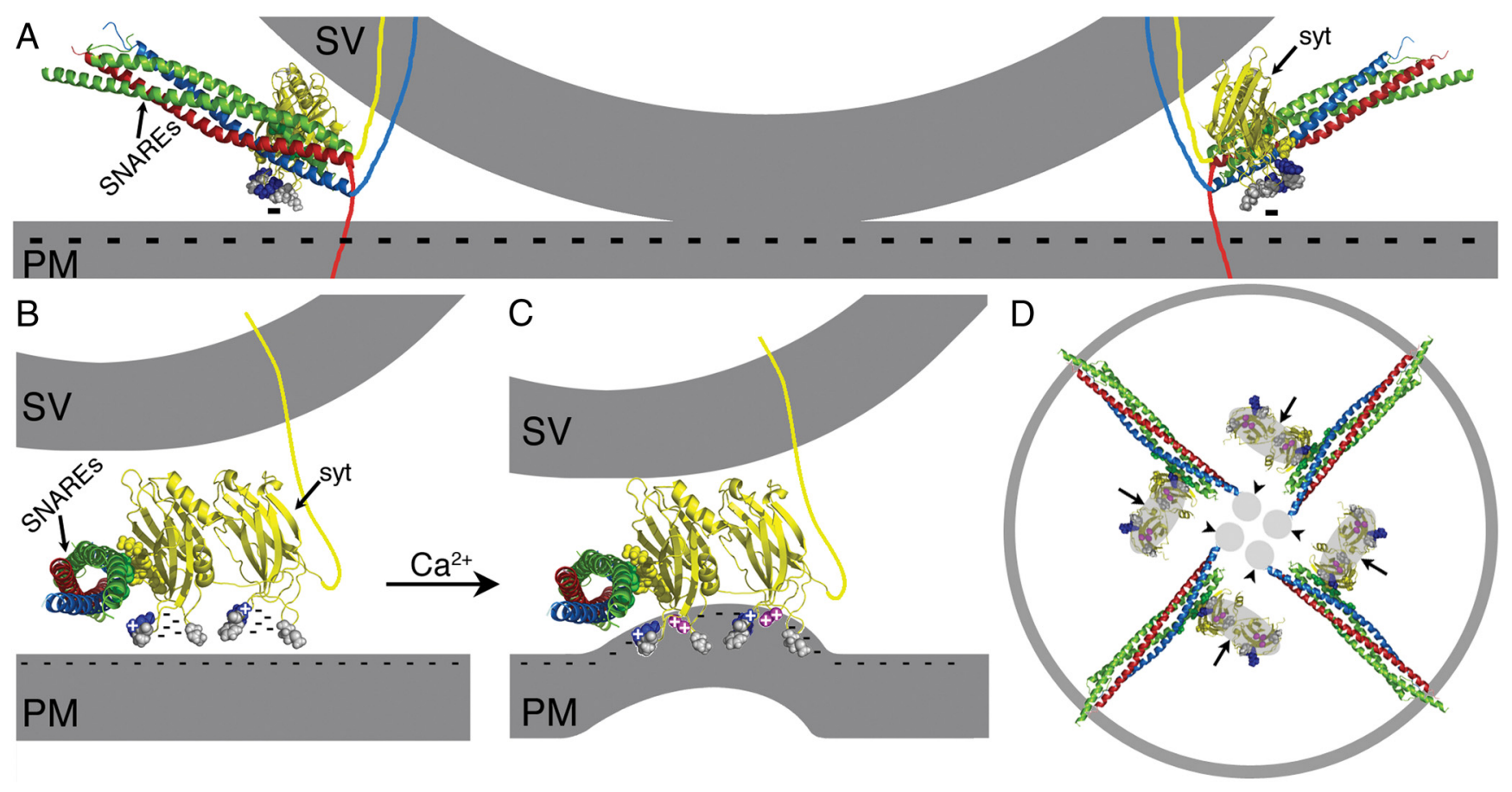

Figure 9. Model of the role of $\mathrm{Ca}^{2+}$-dependent penetration of the anionic presynaptic membrane by synaptotagmin. The crystal structure of the core complex [Protein Data Bank (PDB) file 1SFC, containing syntaxin (red), SNAP-25 (synapse associated protein of $25 \mathrm{kD}$ ) (green), and VAMP (vesicle-associated membrane protein)/synaptobrevin (blue)], the nuclear magnetic resonance structures of the $\mathrm{C}_{2} \mathrm{~A}$ (PDB file $1 \mathrm{BYN}$ ) and $\mathrm{C}_{2} \mathrm{~B}$ (PDB file 1K5W) domains of synaptotagmin (yellow), and $\mathrm{Ca}^{2+}$ (pink "+") were rendered using PyMOL Molecular Graphics System (DeLano Scientific). The synaptic vesicle (SV), the presynaptic membrane (PM), the transmembrane domains, and the link between $C_{2} A$ and $C_{2} B$ were added in Adobe Photoshop. $A$, Docked synaptic vesicle with two synaptotagmin/SNARE complexes shown. $\boldsymbol{B}$, syt/SNARE complex viewed end on from the site of synaptic vesicle/presynaptic membrane apposition (SNARE complex transmembrane domains in front of plane of section). $\mathrm{Ca}^{2+}$-independent priming between the $\mathrm{C}_{2} \mathrm{~B}$ polylysine motif (yellow, space-filled residues) and SNAP-25 [green, space-filled residues (Zhang et al., 2002 ; Rickman et al., 2004; Loewen et al., 2006b)] holds the $\mathrm{C}_{2} \mathrm{BCa}^{2+}$-binding site immediately adjacent to the SNARE complex and the $\mathrm{C}_{2} \mathrm{ACa}^{2+}$-binding site nearby. The negative charge of the $\mathrm{Ca}^{2+}$-binding pockets (cluster of - symbols) prevents interactions between the tips of the $C_{2}$ domains and the presynaptic membrane attributable to electrostatic repulsion. $C_{\text {, }} \mathrm{Ca}^{2+}$ binding neutralizes the negative charge of the pockets resulting in a strong attraction of the negatively charged, phospholipid head groups of the presynaptic membrane by the bound $\mathrm{Ca}^{2+}$ (pink spheres + ) and the basic residues at the tips of $\mathrm{Ca}^{2+}$-binding pockets (blue, space-filled residues + ). Insertion of the hydrophobic residues at the tips of the $C_{2}$ domains (gray, space-filled residues) into the core of the presynaptic membrane and then triggers fusion by promoting a local $\mathrm{Ca}^{2+}$-dependent buckling of the plasma membrane (Martens et al., 2007; Hui et al., 2009). D, syt/SNARE complexes viewed from the presynaptic membrane. Multiple syt:SNARE complexes (colored as in A-C) mediate fusion (Jahn and Scheller, 2006) of a single synaptic vesicle (gray ring, not to scale). (a ${ }^{2+}$-dependent membrane penetration by synaptotagmin (large gray ovals, arrows) pulls the presynaptic membrane toward the vesicle in the vicinity of the transmembrane regions of the SNARE complexes (small gray circles, arrowheads).

plex facilitates vesicle fusion. Another mutation that abolishes $\mathrm{Ca}^{2+}$-dependent SNARE interactions [R199A,K200A,K297A, K301A (Lynch et al., 2007)] showed no effect on the ability of the $\mathrm{Ca}^{2+}$-bound $\mathrm{C}_{2} \mathrm{AB}$ domain to stimulate SNARE-mediated liposome fusion in vitro by one group (Gaffaney et al., 2008), indicating that this $\mathrm{Ca}^{2+}$-dependent SNARE interaction may not play a role. Yet another group found that this same mutation, when $\mathrm{Ca}^{2+}$ bound, supports a level of SNARE-mediated liposome fusion that is only halfway between $\mathrm{Ca}^{2+}$-bound, wild-type $\mathrm{C}_{2} \mathrm{AB}$ and $\mathrm{Ca}^{2+}$-free, wild-type $\mathrm{C}_{2} \mathrm{AB}$ (Lynch et al., 2007), indicating that this interaction provides a facilitatory effect similar to the interactions listed above. This mutant failed to rescue large dense-core vesicle (LDCV) fusion in PC12 cells, suggesting that the SNARE interaction plays a more important role in this system (Lynch et al., 2007). However, the properties of LDCV fusion are different from those of synaptic vesicle fusion in terms of timing and $\mathrm{Ca}^{2+}$ sensitivity (Kasai, 1999). Importantly, in PC12 cells, introduction of synaptotagmin I that contains aspartate to asparagine mutations in the $\mathrm{C}_{2} \mathrm{~A} \mathrm{Ca}^{2+}$-binding motif causes a $60 \%$ decrease in evoked release (Wang et al., 2006), whereas the same mutations do not inhibit evoked release at synapses (FernándezChacón et al., 2002; Robinson et al., 2002). In addition, the positively charged residues at the tips of the $\mathrm{C}_{2}$ domains (Fig. 9, blue space-filled residues, + ) are equally important during LDCV fu- sion [mutation of either results in a $\sim 50 \%$ decrease in fusion (Wang et al., 2003)], whereas this residue in $\mathrm{C}_{2} \mathrm{~B}$ is more critical than in $\mathrm{C}_{2} \mathrm{~A}$ for synaptic vesicle fusion at an intact synapse $[80 \%$ inhibition in $\mathrm{C}_{2} \mathrm{~B}$ mutant and $50 \%$ inhibition in $\mathrm{C}_{2} \mathrm{~A}$ mutant (Paddock et al., 2008)]. These discrepancies indicate a shift in the relative role of the $\mathrm{C}_{2} \mathrm{~A}$ and $\mathrm{C}_{2} \mathrm{~B}$ domains between these systems with both $\mathrm{C}_{2}$ domains participating in the $\mathrm{Ca}^{2+}$-sensing function during LDCV fusion in PC12 cells, whereas $\mathrm{C}_{2} \mathrm{~B}$ fulfills the more critical role at the synapse. Although interactions with the SNARE complex are clearly important in facilitating vesicle fusion, whether they are required for fusion at the synapse has not been tested.

Synaptotagmin mutants that block $\mathrm{Ca}^{2+}$-dependent membrane penetration would have a dominant-negative effect (i.e., inhibit the action of wild-type synaptotagmin) because multiple synaptotagmin:SNARE complexes are required to fuse a single synaptic vesicle (Fig. 9A,D) (Jahn and Scheller, 2006). As these nonfunctional mutants displace native synaptotagmin, synaptic efficacy declines. Our $\mathrm{C}_{2} \mathrm{~B}$ hydrophobic mutant and the $\mathrm{C}_{2} \mathrm{~B}$ $\mathrm{Ca}^{2+}$-binding motif mutants fall into this category. Our finding that expression of the syt ${ }^{\mathrm{B}-\mathrm{IE}}$ mutant results in embryonic lethality in the presence of native synaptotagmin (Table 1) indicates that disruption of $\mathrm{C}_{2} \mathrm{~B}$ membrane penetration of even a fraction of the synaptotagmin molecules in the synaptotagmin:SNARE 
complexes mediating fusion is lethal. However, $\mathrm{C}_{2} \mathrm{~B} \mathrm{Ca}^{2+}{ }_{-}$ binding motif mutants, which also disrupt $\mathrm{Ca}^{2+}$-dependent interactions with negatively charged phospholipids, reduce evoked transmitter release and only impair viability when coexpressed with native synaptotagmin (Mackler et al., 2002). This apparent discrepancy may be explained by the nature of the mutations of the $\mathrm{C}_{2} \mathrm{~B} \mathrm{Ca}^{2+}$-binding motif. Aspartate to asparagine mutations (DtoN) would partially neutralize the negative charge of the $\mathrm{Ca}^{2+}$-binding pocket similar to the action of $\mathrm{Ca}^{2+}$. Indeed, syt ${ }^{\text {DtoN }}$ mutations in $\mathrm{C}_{2} \mathrm{~A}$ partially mimic $\mathrm{Ca}^{2+}$ binding (Stevens and Sullivan, 2003). Because the positively charged residue at the tip of the pocket (Fig. 9, blue space-filled residue, + ) remains intact in syt ${ }^{\text {B-DtoN }}$ mutants to attract the presynaptic membrane, the hydrophobic residues at the tip of the $\mathrm{C}_{2} \mathrm{~B} \mathrm{Ca}^{2+}$-binding pocket may be able to insert into the membrane, at least partially. Thus, syt ${ }^{\mathrm{B}-\mathrm{DtoN}}$ mutations, by permitting partial membrane insertion, would have a less severe dominant-negative effect on native synaptotagmin than the syt ${ }^{\mathrm{B}-\mathrm{IE}}$ mutation.

In summary, the syt ${ }^{\mathrm{B}-\mathrm{IE}}$ mutation is the first effector interaction mutation to inhibit evoked release below levels seen in syt $t^{\text {null }}$ mutants, similar to the $\mathrm{C}_{2} \mathrm{~B} \mathrm{Ca}^{2+}$-binding motif mutations. The lethality exhibited in the $P\left[s y t^{B-I E}\right]$ mutants, even in the presence of native synaptotagmin, demonstrates that mutation of a single hydrophobic residue in $\mathrm{C}_{2} \mathrm{~B}$ results in the most severe disruption of synaptotagmin function to date. These findings strongly support the hypothesis that membrane penetration by the $\mathrm{C}_{2} \mathrm{~B}$ domain of synaptotagmin is the key effector interaction required for triggering $\mathrm{Ca}^{2+}$-dependent synaptic vesicle fusion.

\section{References}

Bai J, Wang P, Chapman ER (2002) C2A activates a cryptic $\mathrm{Ca}^{2+}$-triggered membrane penetration activity within the $\mathrm{C} 2 \mathrm{~B}$ domain of synaptotagmin I. Proc Natl Acad Sci U S A 99:1665-1670.

Brand AH, Perrimon N (1993) Targeted gene expression as a means of altering cell fates and generating dominant phenotypes. Development 118:401-415.

Broadie K, Bellen HJ, DiAntonio A, Littleton JT, Schwarz TL (1994) Absence of synaptotagmin disrupts excitation-secretion coupling during synaptic transmission. Proc Natl Acad Sci U S A 91:10727-10731.

Chapman ER, Hanson PI, An S, Jahn R (1995) $\mathrm{Ca}^{2+}$ regulates the interaction between synaptotagmin and syntaxin 1. J Biol Chem 270:23667-23671.

Chen K, Featherstone DE, Broadie K (2009) Electrophysiological recording in the Drosophila embryo. J Vis Exp pii:1348.

Chicka MC, Hui E, Liu H, Chapman ER (2008) Synaptotagmin arrests the SNARE complex before triggering fast, efficient membrane fusion in response to $\mathrm{Ca}^{2+}$. Nat Struct Mol Biol 15:827-835.

Davletov B, Perisic O, Williams RL (1998) Calcium-dependent membrane penetration is a hallmark of the $\mathrm{C} 2$ domain of cytosolic phospholipase $\mathrm{A} 2$ whereas the $\mathrm{C} 2 \mathrm{~A}$ domain of synaptotagmin binds membranes electrostatically. J Biol Chem 273:19093-19096.

DiAntonio A, Schwarz TL (1994) The effect on synaptic physiology of synaptotagmin mutations in Drosophila. Neuron 12:909-920.

Featherstone DE, Chen K, Broadie K (2009) Harvesting and preparing Drosophila embryos for electrophysiological recording and other procedures. J Vis Exp pii:1347.

Fernández-Chacón R, Königstorfer A, Gerber SH, García J, Matos MF, Stevens CF, Brose N, Rizo J, Rosenmund C, Südhof TC (2001) Synaptotagmin I functions as a calcium regulator of release probability. Nature 410:41-49.

Fernández-Chacón R, Shin OH, Königstorfer A, Matos MF, Meyer AC, Garcia J, Gerber SH, Rizo J, Südhof TC, Rosenmund C (2002) Structure/ function analysis of $\mathrm{Ca}^{2+}$ binding to the $\mathrm{C} 2 \mathrm{~A}$ domain of synaptotagmin $\mathrm{I}$. J Neurosci 22:8438-8446.

Gaffaney JD, Dunning FM, Wang Z, Hui E, Chapman ER (2008) Synaptotagmin $\mathrm{C} 2 \mathrm{~B}$ domain regulates $\mathrm{Ca}^{2+}$-triggered fusion in vitro: critical residues revealed by scanning alanine mutagenesis. J Biol Chem 283:31763-31775.
Geppert M, Goda Y, Hammer RE, Li C, Rosahl TW, Stevens CF, Südhof TC (1994) Synaptotagmin I: a major $\mathrm{Ca}^{2+}$ sensor for transmitter release at a central synapse. Cell 79:717-727.

Gerona RR, Larsen EC, Kowalchyk JA, Martin TF (2000) The C terminus of SNAP25 is essential for $\mathrm{Ca}^{2+}$-dependent binding of synaptotagmin to SNARE complexes. J Biol Chem 275:6328-6336.

Herrick DZ, Sterbling S, Rasch KA, Hinderliter A, Cafiso DS (2006) Position of synaptotagmin I at the membrane interface: cooperative interactions of tandem C2 domains. Biochemistry 45:9668-9674.

Hui E, Johnson CP, Yao J, Dunning FM, Chapman ER (2009) Synaptotagmin-mediated bending of the target membrane is a critical step in $\mathrm{Ca}^{2+}$-regulated fusion. Cell 138:709-721.

Jahn R, Scheller RH (2006) SNAREs: engines for membrane fusion. Nat Rev Mol Cell Biol 7:631-643.

Jorgensen EM, Hartwieg E, Schuske K, Nonet ML, Jin Y, Horvitz HR (1995) Defective recycling of synaptic vesicles in synaptotagmin mutants of Caenorhabditis elegans. Nature 378:196-199.

Kasai H (1999) Comparative biology of $\mathrm{Ca}^{2+}$-dependent exocytosis: implications of kinetic diversity for secretory function. Trends Neurosci 22:88-93.

Lang T, Jahn R (2008) Core proteins of the secretory machinery. Handb Exp Pharmacol 184:107-127.

Li L, Shin OH, Rhee JS, Araç D, Rah JC, Rizo J, Südhof T, Rosenmund C (2006) Phosphatidylinositol phosphates as co-activators of $\mathrm{Ca}^{2+}$ binding to C2 domains of synaptotagmin 1. J Biol Chem 281:15845-15852.

Littleton JT, Stern M, Perin M, Bellen HJ (1994) Calcium dependence of neurotransmitter release and rate of spontaneous vesicle fusions are altered in Drosophila synaptotagmin mutants. Proc Natl Acad Sci U S A 91:10888-10892.

Loewen CA, Mackler JM, Reist NE (2001) Drosophila synaptotagmin I null mutants survive to early adulthood. Genesis 31:30-36.

Loewen CA, Royer SM, Reist NE (2006a) Drosophila synaptotagmin I null mutants show severe alterations in vesicle populations but calciumbinding motif mutants do not. J Comp Neurol 496:1-12.

Loewen CA, Lee SM, Shin YK, Reist NE (2006b) C2B polylysine motif of synaptotagmin facilitates a $\mathrm{Ca}^{2+}$-independent stage of synaptic vesicle priming in vivo. Mol Biol Cell 17:5211-5226.

Lynch KL, Gerona RR, Larsen EC, Marcia RF, Mitchell JC, Martin TF (2007) Synaptotagmin C2A loop 2 mediates $\mathrm{Ca}^{2+}$-dependent SNARE interactions essential for $\mathrm{Ca}^{2+}$-triggered vesicle exocytosis. Mol Biol Cell 18:4957-4968.

Lynch KL, Gerona RR, Kielar DM, Martens S, McMahon HT, Martin TF (2008) Synaptotagmin-1 utilizes membrane bending and SNARE binding to drive fusion pore expansion. Mol Biol Cell 19:5093-5103.

Mackler JM, Reist NE (2001) Mutations in the second $\mathrm{C}_{2}$ domain of synaptotagmin disrupt synaptic transmission at Drosophila neuromuscular junctions. J Comp Neurol 436:4-16.

Mackler JM, Drummond JA, Loewen CA, Robinson IM, Reist NE (2002) The $\mathrm{C}_{2} \mathrm{~B} \mathrm{Ca}^{2+}$-binding motif of synaptotagmin is required for synaptic transmission in vivo. Nature 418:340-344.

Martens S, Kozlov MM, McMahon HT (2007) How synaptotagmin promotes membrane fusion. Science 316:1205-1208.

Mastrogiacomo A, Parsons SM, Zampighi GA, Jenden DJ, Umbach JA, Gundersen CB (1994) Cysteine string protein: a potential link between synaptic vesicles and presynaptic $\mathrm{Ca}^{2+}$ channels. Science 263:981-982.

Nishiki T, Augustine GJ (2004) Dual roles of the C2B domain of synaptotagmin I in synchronizing $\mathrm{Ca}^{2+}$-dependent neurotransmitter release. J Neurosci 24:8542-8550.

Paddock BE, Striegel AR, Hui E, Chapman ER, Reist NE (2008) $\mathrm{Ca}^{2+}$. dependent, phospholipid-binding residues of synaptotagmin are critical for excitation-secretion coupling in vivo. J Neurosci 28:7458-7466.

Reist NE, Buchanan J, Li J, DiAntonio A, Buxton EM, Schwarz TL (1998) Morphologically docked synaptic vesicles are reduced in synaptotagmin mutants of Drosophila. J Neurosci 18:7662-7673.

Rhee JS, Li LY, Shin OH, Rah JC, Rizo J, Südhof TC, Rosenmund C (2005) Augmenting neurotransmitter release by enhancing the apparent $\mathrm{Ca}^{2+}$ affinity of synaptotagmin 1. Proc Natl Acad Sci U S A 102:18664-18669.

Rickman C, Archer DA, Meunier FA, Craxton M, Fukuda M, Burgoyne RD, Davletov B (2004) Synaptotagmin interaction with the syntaxin/ SNAP-25 dimer is mediated by an evolutionarily conserved motif and is sensitive to inositol hexakisphosphate. J Biol Chem 279:12574-12579. 
Rizo J, Rosenmund C (2008) Synaptic vesicle fusion. Nat Struct Mol Biol 15:665-674.

Robinson IM, Ranjan R, Schwarz TL (2002) Synaptotagmins I and IV promote transmitter release independently of $\mathrm{Ca}^{2+}$ binding in the $\mathrm{C}_{2} \mathrm{~A}$ domain. Nature 418:336-340.

Shin OH, Rhee JS, Tang J, Sugita S, Rosenmund C, Südhof TC (2003) $\mathrm{Sr}^{2+}$ binding to the $\mathrm{Ca}^{2+}$ binding site of the synaptotagmin $1 \mathrm{C} 2 \mathrm{~B}$ domain triggers fast exocytosis without stimulating SNARE interactions. Neuron 37:99-108.

Stevens CF, Sullivan JM (2003) The synaptotagmin C2A domain is part of the calcium sensor controlling fast synaptic transmission. Neuron 39:299-308.

Stewart BA, Atwood HL, Renger JJ, Wang J, Wu CF (1994) Improved stability of Drosophila larval neuromuscular preparations in haemolymphlike physiological solutions. J Comp Physiol A Neuroethol Sens Neural Behav Physiol 175:179-191.

Ubach J, Zhang X, Shao X, Südhof TC, Rizo J (1998) $\mathrm{Ca}^{2+}$ binding to synaptotagmin: how many $\mathrm{Ca}^{2+}$ ions bind to the tip of a C2-domain? EMBO 17:3921-3930.

Wang CT, Bai J, Chang PY, Chapman ER, Jackson MB (2006) Synaptotagmin- $\mathrm{Ca}^{2+}$ triggers two sequential steps in regulated exocytosis in rat PC12 cells: fusion pore opening and fusion pore dilation. J Physiol 570:295-307.

Wang P, Wang CT, Bai J, Jackson MB, Chapman ER (2003) Mutations in the effector binding loops in the $\mathrm{C} 2 \mathrm{~A}$ and $\mathrm{C} 2 \mathrm{~B}$ domains of synaptotagmin I disrupt exocytosis in a nonadditive manner. J Biol Chem 278:47030-47037.

Weber T, Zemelman BV, McNew JA, Westermann B, Gmachl M, Parlati F, Söllner TH, Rothman JE (1998) SNAREpins: minimal machinery for membrane fusion. Cell 92:759-772.

Yao KM, White K (1994) Neural specificity of elav expression: defining a Drosophila promoter for directing expression to the nervous system. J Neurochem 63:41-51.

Yoshihara M, Littleton JT (2002) Synaptotagmin I functions as a calcium sensor to synchronize neurotransmitter release. Neuron 36:897-908.

Zhang X, Kim-Miller MJ, Fukuda M, Kowalchyk JA, Martin TF (2002) $\mathrm{Ca}^{2+}$-dependent synaptotagmin binding to SNAP-25 is essential for $\mathrm{Ca}^{2+}$-triggered exocytosis. Neuron 34:599-611.

Zinsmaier KE, Eberle KK, Buchner E, Walter N, Benzer S (1994) Paralysis and early death in cysteine string protein mutants of Drosophila. Science 263:977-980. 